\title{
PEMANFAATAN Baringtonia asiatica DAN Annona muricata TERHADAP SERANGGA VEKTOR PENYAKIT PADA TANAMAN CABAI
}

\section{THE USE OF Baringtonia asiatica AND Annona muricata TO CONTROL INSECTS DISEASE VECTOR ON CHILI PLANTS}

\author{
Christina L. Salaki dan Jantje Pelealu*) \\ "Jurusan Hama dan Penyakit Tumbuhan Fakultas Pertanian Universitas Sam Ratulangi Manado
}

\begin{abstract}
Insect vectors disease is a major problem for chilli crop production in North Sulawesi. The effect is significant in decreasing crop production. The use of plant-derived insecticide is potential and environmentally friendly way in controlling the insect, as a form of integrated pest management. Seeds of Bitung (Barringtonia asiatica) and seeds of soursop (Annona muricata) plants can be used as an organic insectiside to control the several types of insect vectors in pepper crop. The purpose of this study was to determine effects of the application of extracts of $B$. asiatica and $A$. muricata on the growth of insect vector (Aphis gossypii) in pepper and and determine the extracts's lethal level. This research was conducted in the Green House of Plant Pests and Diseases Department of the Faculty of Agriculture Unsrat Manado, for 6 months time. The research used a complete randomized design consisting of 6 treatments; each treatment was consisted of three replications. The results showed that the percentage of dead insects assay (Aphis gossypii) increased as the concentration of the extract used increased. This study found that the concentration of soursop seed extract at $50 \mathrm{~g} / \mathrm{I}$ and a concentration of $1.75 \%$ Bitung seed extract was the best to be used as a botanical insecticide in controlling the insect population vector (Aphis gossypii) in laboratory conditions. It has an effective lethal concentration for $93,67 \%$ and $90.0 \%$ of all test insect population. Overall bioactivity increased the effectiveness of soursop Bitung seed extract as botanical insecticides.
\end{abstract}

Keywords: Barringtonia asiatica, Annona muricata, Aphis gossypii, chilli plants

\section{ABSTRAK}

Serangga vektor penyakit merupakan masalah utama bagi produksi tanaman cabai di Sulawesi Utara karena dapat menurunkan produksi. Salah satu sarana pengendalian yang memiliki peluang baik untuk dikembangkan dalam menunjang penerapan PHT adalah pemanfaatan bahan insektisida yang berasal tumbuhan. Buah bitung (Barringtonia asiatica) dan biji sirsak (Annona muricata) adalah jenis tumbuhan yang berpotensi untuk dikembangkan dan efektif terhadap beberapa jenis serangga vektor pada tanaman cabai. Tujuan penelitian ini untuk mengetahui pengaruh ekstrak $B$. asiatica dan $A$. muricata terhadap perkembangan dan daya bunuh terhadap serangga vektor (Aphis gossypii) pada tanaman cabai. Penelitian ini dilaksanakan di Green House Jurusan Hama dan Penyakit Tumbuhan Fakultas Pertanian Unsrat Manado, selama kurang lebih 6 bulan. Metode penelitian yang digunakan adalah Rancangan Acak Lengkap yang terdiri dari 6 perlakuan dan tiap perlakuan terdiri dari 3 ulangan. Hasil penelitian menunjukkan bahwa persentase kematian serangga uji (Aphis gossypii) meningkat seiring dengan meningkatnya konsentrasi ekstrak yang digunakan. Dalam penelitian ini didapati bahwa konsentrasi ekstrak biji sirsak sebesar $50 \mathrm{~g} / \mathrm{l}$ dan konsentrasi ekstrak biji bitung 1,75 \% sangat baik digunakan sebagai insektisida botani dalam mengendalikan populasi serangga vektor (Aphis gossypii) pada kondisi laboratorium, karena konsentrasi ini efektif mematikan sebesar 93,67\% dan 90,0\% seluruh populasi serangga uji. Keseluruhan bioaktivitas tersebut menambah keefektifan ekstrak biji sirsak dan buah bitung sebagai insektisida botani.

Kata Kunci : Barringtonia asiatica, Annona muricata, Aphis gossypii, tanaman cabai 


\section{PENDAHULUAN}

Cabai (Capsicum annuum) merupakan salah satu komoditas hortikultura yang memiliki nilai ekonomi penting di Indonesia, karena buahnya selain dijadikan sayuran atau bumbu masak juga mempunyai kapasitas menaikkan pendapatan petani, sebagai bahan baku industri, memiliki peluang eksport, membuka kesempatan kerja serta sebagai sumber vitamin C. Cabai mengandung berbagai macam senyawa yang berguna bagi kesehatan manusia (Sayuti, 2006). Cabai mengandung antioksidan yang berfungsi untuk menjaga tubuh dari serangan radikal bebas. Kandungan terbesar antioksidan ini adalah pada cabai hijau. Cabai juga mengandung Lasparaginase dan Capsaicin yang berperan sebagai zat anti kanker (Anonim, 2011).

Kebutuhan cabai dari tahun ke tahun terus menigkat, ini sejalan dengan menigkatnya jumlah penduduk yang semakin banyak serta berkembangnya serapan dari sektor industri yang menggunakan cabai sebagai bahan baku. Saat ini pemerintah Republik Indonesia lewat Departemen Pertanian menjadikan salah satu dari sepuluh komoditas unggulan hortikultura untuk dikembangkan. Upaya peningkatan produksi cabai sampai saat ini sudah dilakukan baik melalui program intensifikasi ataupun ekstensifikasi.

Salah satu kendala utama dalam sistem produksi cabai di Indonesia adalah adanya serangan hama dan penyakit pada buah cabai. Laporan Departemen Pertanian RI Tahun 2006 menunjukkan bahwa kerusakan pada tanaman cabai di Indonesia dapat mencapai $35 \%$. Buah cabai yang terserang sering tampak sehat dan utuh dari luar tetapi bila dilihat di dalamnya membusuk. Upaya penanggulangan yang sudah dilakukan untuk mengendalikan serangan ini sampai saat ini masih mengandalkan pestisida. Akan tetapi penggunaan insektisida tersebut sering meninggalkan residu yang berbahaya terhadap lingkungan dan kesehatan manusia (Untung, 2006). Di samping harga insektisida sintetik yang mahal, dampak dari adanya residu insektida sintetik dalam bidang ekonomi adalah ekspor oleh banyak Negara tujuan ekspor atas produk-produk cabai yang mengandung residu fungisida dan pestisida lain. Di antara insektisida yang banyak digunakan dalam pengendalian serangga vektor penyakit pada cabai adalah Diazinon, Dursban, Supracide, Tamaron dengan konsentrasi 3-5\%, dan Agrothion (Untung, 2006).

Kekhawatiran akan dampak negatif dari penggunaan insektisida sintetik tersebut menimbulkan kebutuhan akan adanya alternatif baru yang dapat dipakai untuk mengendalikan populasi hama dan serangga vektor sampai pada tingkat yang tidak merugikan secara ekonomi.

Untuk mengatasi permasalahan tersebut, perlu dikembangkan sarana pengendalian hama yang efektif tetapi ramah lingkungan. Salah satu sarana pengendalian yang memiliki peluang baik untuk dikembangkan dalam menunjang penerapan PHT adalah pemanfaatan bahan insektisida yang berasal dari tumbuhan karena relatif aman terhadap musuh alami, memiliki tingkat persistensi yang singkat sehingga tidak dikuatirkan meninggalkan residu, tidak mencemari lingkungan, dan dapat bekerja secara kompatibel dengan pengendalian hayati (Untung, 2006 dan Sembel, 2010).

Sulawesi Utara memiliki banyak tumbuhan yang berpotensi untuk dikembangkan sebagai sumber insektisida botani. Buah bitung (Barringtonia asiatica) dan biji sirsak (Annona muricata) adalah jenis tumbuhan yang berpotensi untuk dikembangkan dan efektif terhadap beberapa jenis serangga hama, namun pengujian dengan menggunakan ekstrak kasar dapat memberikan hasil yang beragam tergantung dari jenis ekstrak yang digunakan, faktor serangga uji dan lingkungan. Walaupun demikian menurut Kardinan (2000) sediaan insektisida botani yang efektif di suatu tempat belum tentu efektif di tempat lain. Salah satu penyebabnya adalah jumlah kandungan bahan aktif yang dimiliki oleh spesies tumbuhan yang sama seringkali berbeda tergantung dari keadaan geografi daerah asal tumbuhan tersebut, sehingga dosis atau konsentrasi yang digunakannya juga akan berbeda.

Tujuan penelitian ini adalah untuk mengetahui pengaruh ekstrak Baringtonia asiatica dan Annona muricata terhadap perkembangan serangga vektor pada tanaman cabai dan 
mengetahui daya bunuh ekstrak Baringtonia asiatica dan Annona muricata terhadap mortalitas serangga vektor (Aphis gossypii) pada tanaman cabai.

\section{METODE PENELITIAN}

Penelitian ini akan dilaksanakan di Laboratorium Entomologi dan Green House Jurusan Hama dan Penyakit Fakultas Pertanian Unsrat Manado selama \pm 3 bulan sejak bulan Januari sampai Maret 2012.

Bahan yang akan digunakan dalam penelitian ini adalah serangga vektor penyakit (Mycus persicae dan Aphis gossypii, bibit tanaman cabai, larutan madu $10 \%$, ekstrak biji bitung (stok dari Frangky Paat. SP,MSi), Ekstrak biji sirsak, aquades, alkohol 70\% dan $95 \%$, polybag, media tanah.

Alat yang akan digunakan kurungan kasa, stoples, timbangan, kain kasa, gelas ukur, handsprayer, labu Erlenmeyer, aluminium foil, loupe, kertas hisap, kuas, kapas, label, gunting, alat tulis menulis dan kamera.

Penelitian dilaksanakan pada kondisi laboratorium. Rancangan percobaan yang digunakan adalah Rancangan Acak Lengkap (RAL).

Sebagai perlakuan adalah konsentrasi biji bitung yaitu: $0.00 \mathrm{gr} / 500 \mathrm{ml}$ air (Kontrol); 0,75 gr Pure Extract $B$. asiatica $+500 \mathrm{ml}$ air $+1.0 \mathrm{ml}$ agristik/twin 29; $1,00 \mathrm{gr}$ Pure Extract $B$. asiatica + $500 \mathrm{ml}$ air + $1.0 \mathrm{ml}$ agristik/twin 29; 1,25 gr Pure Extract B. asiatica $+500 \mathrm{ml}$ air $+1.0 \mathrm{ml}$ agristik/twin 29; 1,50 gr Pure Extract B. asiatica $+500 \mathrm{ml}$ air + $1.0 \mathrm{ml}$ agristik/twin $29 ; 1,75 \mathrm{gr}$ Pure Extract $B$. asiatica $+500 \mathrm{ml}$ air $+1.0 \mathrm{ml}$ agristik/twin 29

Sebagai perlakuan ekstrak biji sirsak : a. 0 gr/l; b. 10 gr/l; c. 20 gr/l; d. 30 gr/l; e. 40 gr/l; f. 50 $\mathrm{gr} / \mathrm{l}$

\section{Prosedur Penelitian}

\section{Perbanyakan Serangga Uji}

Serangga yang digunakan dalam penelitian ini diambil dari lapangan untuk kemudian di perbanyak di laboratorium. Imago dipelihara dalam kotak penangkaran serangga yang didalamnya sudah diletakkan bibit cabai sebagai tempat imago meletakkan telurnya. Sebagai makanan dari imago, diberi larutan madu $10 \%$ yang dioleskan pada segumpal kapas.

Kelompok telur yang diletakkan pada daun tanaman cabai tersebut dikumpulkan dan ditempatkan dalam cawan petri yang dialasi kertas hisap. Setelah telur menetas, nimfanya dipindahkan ke dalam kotak kurungan kecil untuk dijadikan pengujian.

\section{Penyediaan Ekstrak Biji Sirsak}

Biji sirsak yang digunakan berasal dari buah yang telah matang dan bijinya berwarna hitam. Biji dikeringanginkan terlebih dahulu selama 7 hari dan kemudian dikupas untuk diambil isinya. Isi biji sirsak tersebut dihaluskan dengan menggunakan blender kering hingga menjadi serbuk. Untuk memperoleh konsentrasi ekstrak $10 \mathrm{gr} / \mathrm{l}$ maka diambil $10 \mathrm{gr}$ biji sirsak dan ditambahkan 1 liter aquades yang mengandung $0,50 \mathrm{gr}$ deterjen bubuk dan diblender selama 30 menit, konsentrasi ekstrak $20 \mathrm{gr} / \mathrm{l}$ maka diambil $20 \mathrm{gr}$ biji sirsak dan ditambahkan 1 liter aquades yang mengandung $0,50 \mathrm{gr}$ detergen bubuk dan diblender, demikian seterusnya untuk 30, 40 dan $50 \mathrm{gr} / \mathrm{l}$. Selanjutnya ekstrak disaring dengan menggunakan kain tetron, dimasukkan dalam wadah yang tertutup.

\section{Aplikasi Ekstrak Biji Bitung (B. asiatica) dan Biji Sirsak (A. muricata)}

Aplikasi ekstrak biji bitung (B. asiatica) pada serangga uji dilakukan dengan menyemprotkan suspensi ekstrak dengan konsentrasi 0.75 $\mathrm{gr} / 500 \mathrm{ml}, 1.00 \mathrm{gr} / 500 \mathrm{ml}, 1.25 \mathrm{gr} / 500 \mathrm{ml}, 1.50$ $\mathrm{gr} / 500 \mathrm{ml}, 1.75 \mathrm{gr} / 500 \mathrm{ml}$ dan kontrol untuk biji bitung dan konsentrasi $10 \mathrm{gr} / \mathrm{ml}, 20 \mathrm{gr} / \mathrm{l}, 30 \mathrm{gr} / \mathrm{l}, 40 \mathrm{gr} / \mathrm{l}, 50$ $\mathrm{gr} / \mathrm{l}$ dan kontrol untuk biji sirsak pada bibit tanaman cabai yang telah dimasukkan dalam kurungan. Masing-masing perlakuan diinvestasi dengan nimfa sebanyak 30 ekor. Setelah 24 jam baik pada perlakuan maupun kontrol.

\section{Pengamatan}

Parameter yang diamati antara lain mortalitas nimfa berdasarkan hari setelah perlakuan dan berdasarkan fase perkembangannya nimfa dari instar 1 sampai instar 5. Pengamatan dilakukan 
setiap hari sampai dewasa. Data persentase mortalitas perlakuan yang diperoleh dikoreksi dengan mortalitas kontrol dengan rumus Abbott' :

$$
P t=\frac{\left(P_{0}-P_{c}\right)}{\left(100-P_{c}\right)} \times 100 \%
$$

$\mathrm{Pt}=$ mortalitas terkoreksi

$P_{\mathrm{c}}=$ mortalitas perlakuan

$\mathrm{P}_{0}=$ mortalitas kontrol

\section{Analisis Data}

Data yang diperoleh dianalisis dengan menggunakan analisis sidik ragam, bilamana perlakuan memberikan pengaruh yang nyata maka dilanjutkan dengan uji Beda Nyata Terkecil (BNT).

\section{HASIL DAN PEMBAHASAN}

\section{Ekstrak Biji Sirsak}

Berdasarkan hasil pengamatan mortalitas Aphis gossypii sesudah diaplikasi dengan ekstrak biji sirsak pada beberapa konsentrasi yaitu $10 \mathrm{gr} / \mathrm{l}$, $20 \mathrm{gr} / \mathrm{l}, 30 \mathrm{gr} / \mathrm{l}, 40 \mathrm{gr} / \mathrm{l}, 50 \mathrm{gr} / \mathrm{l}$ dan kontrol menunjukkan angka yang berbeda. Pengamatan hari pertama terlihat sejumlah nimfa yang mati. Data rata-rata jumah nimfa yang mati dapat dilihat pada tabel 1.

Dari tabel 1 terlihat bahwa rata-rata persentase kematian serangga veletor Aphis gossypii meningkat serupa dengan meningkatnya jumlah ekstrak biji sirsak. Terjadi demikian mungkin berkaitan dengan sifat senyawa acetogonin yang dikandung sirsak; yakni bila konsentrasi acetogonin yang diaplikasikan rendah maka senyawa ini menjadi racun perut (bisa juga menuaikan) namun pada konsentrasi sebaliknya menyebabkan serangga tidak mau makan (Susanti et.al., 2008; Sri Muharsini et.al., 2008; Anonim, 2012; Islamiarto, 2012). Data rata-rata persentase mortalitas Aphis gossypii karena perlakuan ekstrak biji sirsak berbeda mengindikasikan bahwa pada perlakuan ekstrak biji sirsak pada perlakuan $30 \mathrm{gr} / \mathrm{l}$ cukup efektif digunakan sebagai inseleksida notani dalam mengendalikan serangga vektor Aphis gossypii karena sudah mampu mematikan $63,33 \%$ dari jumlah keseluruhan serangga uji yg telah di aplikasikan dengan ekstrak biji sirsak dibandingkan dengan kematian serangga uji pada kontrol 96,67\%. Menurut Priyono (2003) dan Herit et.al. (2002) senyawa acetogenin dari tanaman Annonaceae memiliki efek kontak yang cukup baik terhadap serangga. Hal ini sesuai dengan pengamatan bahwa semakin tinggi konsentrasi ekstrak biji sirsak yang disemprotkan pada serangga vektor maka makin banyak pula racun yang terutama pada kulit serangga. Dengan demikian semakin tinggi ekstrak maka kematian serangga vektor Aphis gossypii makin banyak. Pada perlakuan $40 \mathrm{gr} / \mathrm{l}$ dan $50 \mathrm{gr} / \mathrm{l}$ tidak ada perbedaan yang nyata antara kedua perlakuan tersebut terhadap mortalitas serangga vektor Aphis gossypii. Priyono (1999) mengemukakan bahwa syarat batas pengujian eksrak tanaman bioaktif menggunakan konsentrasi ekstrak tertinggi yaitu 50 gr/l. Karena berdasarkan pengalaman konsentrasi tersebut merupakan batas kelayakan untuk penggunaan ekstrak di lapang. Ekstrak yang tidak efektif lebih lanjut. Ekstrak biji sirsak $50 \mathrm{gr} / \mathrm{l}$ tidak perlu diteliti lebih lanjut. Ekstrak biji sirsak $50 \mathrm{gr} / \mathrm{l}$ efektif untuk mengendalikan hama serangga vektor Aphis gossypii karena perlakuan dengan konsentrasi kematian hingga 93,67\% dari kesuluruhan populasi serangga uji. Hal ini berhenti sesuai dengan yang dikemukakan Priyono (1994) bahwa suatu ekstrak dikatakan efektif bila perlakuan dengan ekstrak tersebut dapat mengakibatkan tingkat kematian $\geq$ $90 \%$.

\section{Ekstrak Biji Bitung (Baringtonia asiatica)}

Hasil pengamatan mortalitas serangga vektor Aphis gossypii sesudah diaplikasi dengan ekstrak murni $B$. asiatica dengan ima konsentrasi $(0,75 \%, 1,0 \%, 1,25 \%, 1,50 \%$ dan $1,75 \%)$ yang dilarutkan dalam $500 \mathrm{ml}$ air dan kontrol (Tabel 2) menunjukkan angka yang berbeda. Dari hasil analisis ragam menunjukkan bahwa di antara perlakuan terdapat perbedaan yang sangat nyata. Rata-rata persentase mortalitas serangga vektor Aphis gossypii yang diaplikasikan dengan berbagai konsentrasi $B$. asiatica dapat dilihat pada tabel 2 . 
Tabel 1: Beda Rata-rata Persentase Mortalitas Serangga Uji dengan Perlakuan Ekstrak Biji Sirsak (Table 1. Different the Average Percentage of Insect Mortality Trials With Soursop Seed Extract Treatment)

\begin{tabular}{ccc}
\hline Perlakuan & Rata-rata Persentase Mortalitas Aphis gossypii $(\%)$ & Notasi \\
\hline Kontrol & 6,67 & $\mathrm{a}^{*}$ \\
$10 \mathrm{~g} / \mathrm{l}$ & 23,33 & $\mathrm{~B}$ \\
$20 \mathrm{~g} / \mathrm{l}$ & 36,67 & $\mathrm{C}$ \\
$30 \mathrm{~g} / \mathrm{l}$ & 63,33 & $\mathrm{D}$ \\
$40 \mathrm{~g} / \mathrm{l}$ & 86,67 & $\mathrm{E}$ \\
$50 \mathrm{~g} / \mathrm{l}$ & 93,67 & $\mathrm{E}$ \\
\hline Bnt $5 \%$ & 10,76 &
\end{tabular}

$\left.{ }^{\star}\right)$ Angka yang diikuti huruf yang sama tidak menunjukkan perbedaan

Tabel 2. Beda Rata-rata Persentase Mortalitas Serangga Vektor Aphis gossypii dengan Perlakuan Ekstrak $B$. asiatica

(Table 2. Different the Average Percentage Mortality of the Insect Vector Aphis gossypii with Extract Treatment B. asiatica)

\begin{tabular}{ccc}
\hline Perlakuan & Rata-rata Persentase Mortalitas Aphis gossypii (\%) & Notasi \\
\hline Kontrol & 0,07 & $\mathrm{a}^{*}$ \\
$0,75 \%$ & 16,67 & $\mathrm{~b}$ \\
$1,00 \%$ & 33,33 & $\mathrm{c}$ \\
$1,25 \%$ & 56,67 & $\mathrm{~d}$ \\
$1,50 \%$ & 86,67 & $\mathrm{e}$ \\
$1,75 \%$ & 90,00 & $\mathrm{e}$ \\
\hline BNT $5 \%$ & 12,01 &
\end{tabular}

*) Angka yang diikuti huruf yang sama tidak menunjukkan perbedaan

Hasil analisis keragaman persentase mortalitas serangga vektor Aphis gossypii menunjukkan terdapat perbedaan yang sangat nyata. Serangga uji telah disemprot dengan berbagai konsentrasi ekstrak $B$. asiatica, pada waktu mulai nampak sejumlah nimfa yang mati. Namun ada beberapa, yang belum mati pada stadia tersebut dan tetap hidup sampai stadia dewasa. Pada perlakuan 1,25 gr/l sudah dapat mematikan serangga uji sebesar $56,6 \%$ dan pada perlakuan 1,75 gr/l dapat mematikan 90,0\%. Gejala kematian yang ditunjukan oleh serangga uji yang terinfeksi $B$. asiatica adalah aktifitas daya makan menurun, pergerakan menjadi lambat dan kemudian mati. Penghambatan aktivitas makan dan kematian serangga uji disebabkan oleh lamanya pemaparan dan pengaruh senyawa glikosida oleanan derivat saponin yang terdapat pada ekstrak $B$. asiatica yang dapat menghambat aktivitas makan dan menyebabkan kematian pada serangga uji.
Adanya hambatan aktifitas makan pada serangga yang diuji disebabkan karena serangga dapat mengenali dan merasakan keberadaan senyawa kimia dalam jumlah tertentu dalam makanan. Serangga akan mengalami dua hal untuk memulai aktivitas makan yaitu adanya rangsanganrangsangan untuk inisiasi aktivitas makan dalam tanaman yang memberikan stimulasi untuk pengenalan makanan dan menjaga aktivitas makan. Kedua adalah pendeteksian kehadiran senyawa-senyawa asing yang dapat bersifat sebagai penghambat makan sehingga dapat memperpendek aktivitas makan dan menghentikan aktivitas makan (Priyono, 1999). Seperti senyawa antifidan yang lain, senyawa saponin dalam ekstrak biji $B$. asiatica diduga dapat mematikan serangga vektor secara tidak langsung dengan cara menyebabkan gangguan pada sistem pengiriman sinyal perangsang makan (phagostimulant) pada serangga. 
Antifidan merupakan senyawa kimia yang bersifat menghambat aktivitas makan serangga, akan tetapi tidak bersifat membunuh, mengusir atau menjerat serangga secara langsung. Senyawa antifidan hanya menghambat nafsu makan (feeding inhibition) pada serangga. Senyawa antifidan bersifat suppresant (menekan aktivitas menggigit) dan detterent (mencegah serangga terus makan (Dono dan Sujana, 2007; Dono et.al., 2008, Hermawan et.al., 2005; Herit et.al., 2002; Khan et.al., 2002)

\section{KESIMPULAN DAN SARAN}

\section{Kesimpulan}

Persentase mortalitas serangga vektor Aphis gossypii meningkat seiring dengan konsentrasi ekstrak yang diaplikasikan.

Konsentrasi ekstrak biji sirsak $50 \mathrm{gr} / \mathrm{l}$ dan konsentrasi ekstrak buah bitung 1,75\% sangat baik digunakan sebagai insektisida botani dalam mengendalikan populasi serangga vektor (Aphis gossypii) pada kondisi laboratorium, karena pada konsentrasi ini efektif mematikan sebesar 93,67\% dan $90,0 \%$ seluruh populasi serangga yang diuji.

\section{Saran}

Perlu dilakukan penelitian lanjutan di lapangan mengenai pengendalian serangga vektor penyakit dengan menggunakan ekstrak biji sirsak dan ekstrak B. asiatica.

\section{UCAPAN TERIMA KASIH}

Penulis menyampaikan terima kasih kepada penyandang dana kegiatan penelitian ini yaitu IPMCRSP USAID dan CLEMSEN University SC, USA yang membantu tim peneliti, sehingga penelitian ini dapat diselesaikan.

\section{DAFTAR PUSTAKA}

Anonim. 2011. Tanaman Cabai. http://www.lestarimandiri.org/id/budidayatanaman-organik/tanaman-sayuran/106budidaya-tanaman-cabe.html.
Anonim. 2012. Pestida Nabati: Ekstrak Biji Sirsak (Annona muricata) dapat Menurunkaan Palatabilitas Ulat Grayak (Spodoptera litura).

Ditjenbun.deptan.go.id/perlindungan/index. php?option=com conten\&view=article\&id.

Dono, D. dan N. Sujana. 2007. Aktivitas insektisidal ekstrak Barringtonia asiatica (L.) Kurz. (Lecythidaceae) Terhadap Larva Crocidolomia pavonana F. (Lepidoptera; Pyralidae) dan Fitotoksisitasnya pada tanaman sawi. Jurnal Agrikultura 18(1):1119.

Dono d., S. Hidayat dan C. Silalahi, 2008. Pengaruh Ekstrak Biji Barringtonia asiatica(L.) Kurz. (Lecythidaceae) terhadap Mortalitas Larva dan Fekunditas Crocidolomia pavonana F. (Lepidoptera; Pyralidae). Jurnal Agrikultura 18(1):11-19.

Herit, E.J., L.N. Mander, E. Pongoh, R.J. Rumampuk dan P. Tarigan. 2002. Two Major saponins from seeds of Barringtonia asiatica putative antifeedants toward Epilachna sp. Larvae. J. Nat. Prod. 65(2):115-120.

Islamianto. 2012. Uji Efektivitas Pasta Biji Sirsak (Annona muricata Linn) dalam Menekan Gall dan Populasi Nematoda (Meloydogyne spp.) pada Tanaman Tomat (Lycopersicum esculentum Mill). Universitas Padjadjaran Bandung.

Kardinan. 2002. Pestisida Nabati Ramuan dan Aplikasi. Jakarta; Penebar Swadaya.

Khan, M.R. dan A.D. Omoloso. 2002. Antibacterial, antifungal activities of Barringtonia asiatica. Fitoterapia 73(3):255-260.

Prijono, D. 1999. Prospek dan Strategi pemanfaatan insektisida Alami dalam PHT. Bahan Pelatihan Pengembangan dan Pemanfaatan Insektisida Alami. Pusat Kajian Pengendalian Hama Terpadu, Institut Pertanian Bogor.

Prijono, D. 2003. Teknik Ekstraksi, Uji Hayati, dan Aplikasi Senyawa Bioaktif Tumbuhan. Departemen Hama dan Penyakit Tumbuhan, Fakultas Pertanian, Institut Pertanian Bogor. 
Sayuti, A. 2006. Geografi Budaya dalam Wilayah Pembangunan Daerah Sumatera Barat. Departemen Pendidikan dan Kebudayaan, Proyek Inventarisasi dan Dokumentasi Kebudayaan Daerah.

Sembel, D.T. 2010. Pengantar Pengendalian Hama Serangga Tropis dan Gulma. Andi Offset. Yogyakarta.

Sri Muharsini., A.H.Wardhana dan Yuningsih. 2008. Uji Keefektifan Biji Sirsak (Annona muricata) dan akar tuba (Derris elliptica) terhadap larva Chrysomya bezziana secara in vitro. Balai Penelitian Veteriner Bogor.
Susanti, V.H., Elfi, Harlita, Ariani dan Sri Retno Dewi. 2008. Isolasi dan Karakterisasi Senyawa Aktif Insektisida dari Biji Sirsak (Annona muricata) Serta Rekayasa Formulasi Ekstraknya untuk Pengendalian Ulat Kubis (Crocidolomia binotalis Zell). Fakultas KIP UNS.

Untung, K. 2006. Pengantar Pengelolaan Hama Terpadu. Gadjah Mada University Press. Yogyakarta. 

